\title{
DEKRIMINALISASI TERHADAP PASAL 127 UNDANG-UNDANG NOMOR 35 TAHUN 2009 TENTANG NARKOTIKA
}

\author{
Widia Ulfa \\ Fakultas Hukum Universitas Jambi \\ widiaulfa212@gmail.com
}

\begin{abstract}
RINGKASAN
Pasal 127 Undang-Undang Nomor 35 Tahun 2009 tentang Narkotika bertentangan dengan tujuan dari dibentuknya UU Narkotika itu sendiri, karena ketentuan pasal ini mengkriminalisasi penyalah guna narkotika dengan pidana penjara maksimal 4 tahun, sementara tujuan dari dibentuknya UU Narkotika dalam Pasal 4 huruf d mengamanatkan bahwa negara wajib untuk menjamin upaya rehabilitasi medis dan sosial bagi penyalah guna dan pecandu narkotika. Ada pula beberapa ketentuan pasal lainnya yang bermasalah dalam perumusan norma karena adanya ketidakjelasan terminologi dalam memandang pecandu, penyalah guna dan korban penyalahgunaan narkotika sehingga mengakibatkan pengaturan lainnya menjadi bias dan simpang siur. Terdapat kekaburan norma dalam UU Narkotika tersebut, menyebabkan terhambatnya pemberian hak rehabilitasi medis dan sosial bagi penyalah guna, pecandu narkotika dan korban penyalahgunaan narkotika. Penelitian ini bertujuan agar Pasal 127 UU Narkotika direkomendasikan untuk dihapuskan atau didekriminalisasi dan selain itu perlu adanya penyempurnaan rumusan atau sinkronisasi istilah terkait pengertian dan status antara pecandu, penyalah guna, dan korban penyalahgunaan narkotika sehingga hak-hak mereka untuk mendapatkan rehabilitasi medis dan sosial dapat dijamin dengan baik.
\end{abstract}

Kata kunci: dekriminalisasi; kriminalisasi; narkotika; rehabilitasi

Perjalanan panjang pengaturan narkotika yang diselimuti kutub pandangan antara pendekatan kriminal dan pendekatan kesehatan berujung dengan dilakukannya perubahan terhadap Undang-Undang terdahulu hingga akhirnya pada tanggal 12 Oktober 2009, UU Narkotika disahkan. Namun pembentukan UU Narkotika ini bukan tanpa celah. Tarik menarik dan perbenturan antara pendekatan kriminal dengan pendekatan kesehatan masyarakat sangat mencuat dalam beberapa pengaturannya. Apabila dicermati lebih dalam, pembentuk UU Narkotika menyadari bahwa harus ada perubahan pendekatan penanganan terhadap pengguna narkotika, yaitu dari pendekatan pemidanaan menjadi pendekatan kesehatan masyarakat.

Hal ini jelas terlihat dalam Pasal 1 angka 13 UU Narkotika yang berbunyi "Pecandu Narkotika adalah orang yang menggunakan atau menyalahgunakan narkotika dan dalam keadaan ketergantungan pada Narkotika, baik secara fisik maupun psikis". Definisi dari pecandu narkotika merujuk pada pandangan bahwa yang bersangkutan berhak untuk mendapatkan pengobatan secara sosial dan medis sehingga dalam banyak pengaturan UU Narkotika mengedepankan hal tersebut. Misalnya Pasal 54, Pasal 103, dan beberapa pasal lainnya yang tertera dalam UU Narkotika. 
Pentingnya

membangun paradigma penghentian kriminalisasi atau dekriminalisasi terhadap penyalah guna narkotika ialah karena penerapan hukuman pidana penjara bagi penyalah guna narkotika di Indonesia terbukti tidak dapat menurunkan jumlah penyalah guna, namun yang sesungguhnya terjadi justru setiap tahun jumlahnya mengalami peningkatan. Lebih lanjut, kriminalisasi terhadap penyalah guna narkotika bertentangan dengan teori viktimologi. Parasian Simanungkalit menyatakan bahwa:

"Menurut perspektif yuridis, pengguna narkoba tidak dapat dikategorisasikan sebagai pelaku kejahatan karena sifat dasar kejahatan haruslah menimbulkan korban dan korban itu adalah orang lain (an act must take place that involves harm inflicted on someone by the actor). Pandangan inilah yang kemudian mengarahkan pada pemahaman bahwa pengguna narkoba merupakan salah satu bentuk dari kejahatan tanpa korban (crime without victim). Hal itu berarti apabila hanya diri sendiri yang menjadi korban, maka hal tersebut tidak dapat dikatakan sebagai kejahatan, sehingga tidak dapat dihukum."1

Artinya, pengguna narkotika tidak dapat dikategorikan sebagai pelaku tindak pidana, melainkan sebagai korban atau pesakitan yang harus diobati, dan dalam hal pemberian pengobatan serta perawatan kepada pengguna narkotika ialah menjadi tanggung jawab negara. Karena dengan menempatkan pengguna narkotika

\footnotetext{
${ }^{1}$ Parasian Simanungkalit, "Model Pemidanaan Yang Ideal Bagi Korban Pengguna Narkoba Di Indonesia", Yustisia Volume 1 Nomor 3, Jakarta, 2012, hal. 81.
}

sebagai pelaku tindak pidana (kriminal) seperti saat ini, upaya-upaya rehabilitatif sering terabaikan. Lebih lanjut menurut Siswanto, "yang menjadi pokok persoalan ialah penyalahgunaan dan peredaran gelap narkotika yang memerlukan strategi pembangunan hukum nasional"2

Semangat

pemberantasan penyalahgunaan narkotika dan perdagangan gelap narkotika, seringkali dilakukan tanpa memperdulikan dan mengabaikan hak-hak pengguna narkotika. Semangat pemberantasan narkotika kadang diartikan sebagai pemberantasan pengguna narkotika dengan cara dikriminalkan, dianggap sebagai sampah masyarakat, dikucilkan dan dianggap sebagai pembawa penyakit sosial dan medis. Stigmatisasi yang melekat pada pengguna narkotika tersebut mengakibatkan hak-haknya sering terabaikan. Keadaan pengguna narkotika yang menjadi korban ketidakmampuaan negara dalam melakukan pengawasan terhadap perdagangan gelap narkotika membuat mereka harus kembali menjadi korban, korban narkotika itu sendiri dan juga korban sistem yang dibuat oleh negara melalui slogan perang terhadap narkotika.

Karena sejatinya kebijakan penetapan pidana dalam perundangundangan merupakan tahap yang paling strategis dilihat dari keseluruhan proses kebijaksanaan untuk mengoperasionalkan sanksi pidana. Sebab penerapan sanksi pidana tersebut akan tercermin dalam putusan hakim yang merupakan badan peradilan pelaksana pidana. Begitu juga yang tercermin dalam putusan hakim terhadap penerapan pidana kepada Penyalah Guna Narkotika yang diatur dalam Pasal 127 ayat (1) UU Narkotika.

\footnotetext{
${ }^{2}$ Siswanto, Politik Hukum Dalam UndangUndang Narkotika (UU Nomor 35 Tahun 2009), Rineka Cipta, Jakarta, 2012, hal. 8.
} 
Sementara Barda Nawawi Arief dalam Mahrus Ali, Dasar-Dasar Hukum Pidana menyatakan bahwa:

"Sesuai dengan sifat sanksi pidana sebagai sanksi terberat atau paling keras dibandingkan dengan jenis-jenis sanksi dalam berbagai bidang hukum yang lain, idealnya fungsionalisasi hukum pidana haruslah ditempatkan sebagai upaya terakhir (ultimum remidium). Penggunaan hukum pidana dalam praktik penegakan hukum seharusnya dilakukan setelah berbagai bidang hukum yang lain itu untuk mengkondisikan masyarakat agar kembali kepada sikap tunduk dan patuh terhadap hukum, dinilai tidak efektif lagi. Fungsi hukum pidana yang demikian dalam teori seringkali pula disebut sebagai fungsi subsidiaritas. Artinya, penggunaan hukum pidana itu haruslah dilakukan secara hati-hati dan penuh dengan berbagai pertimbangan secara komprehensif." 3

Dari penjelasan di atas, dapat kita cermati bahwa hendaknya hukum pidana dengan jenis sanksinya yang khas yaitu pidana penjara ditempatkan sebagai upaya terakhir (ultimum remidium). Sebab selama UU Narkotika masih mencantumkan ancaman pidana penjara bagi penyalah guna narkotika meskipun bagi dirinya sendiri maka hukuman tersebut akan selalu ada. Atas dasar itulah, pengguna atau penyalah guna narkotika dapat dipidanakan, sekalipun dalam pasal yang lain mengatur ketentuan rehabilitasi bagi pengguna narkotika.

${ }^{3}$ Mahrus Ali, Dasar-Dasar Hukum Pidana, Sinar Grafika, Jakarta, 2012, hal. 11.

\section{A. Perumusan Masalah}

Berdasarkan uraian pada latar belakang yang dikemukakan di atas, maka permasalahan yang akan dibahas dalam penelitian ini, adalah:

1. Bagaimana problematika pelaksanaan Undang-Undang Nomor 35 Tahun 2009 tentang Narkotika?

Salah satu hal yang menjadi titik permasalahan dalam UU Narkotika adalah mengenai ketidakjelasan pengertian dan status antara pecandu, penyalah guna, dan korban penyalahgunaan narkotika. Oleh karena ketidakjelasan pada pengertian dan status tersebut, maka pengaturanpengaturan lainnya menjadi bias dan simpang siur. Pada tataran praktik, hal ini secara langsung membawa dampak yang besar terutama bagi pengguna narkotika.

Salah satu dampak praktik yang bias dan simpang siur adalah dalam hal pemberian rehabilitasi medis dan sosial bagi penyalah guna dan pecandu narkotika. Dalam Pasal 4 UU Narkotika, diuraikan salah satu tujuan pembentukan undangundang tersebut adalah guna menjamin upaya rehabilitasi medis dan sosial bagi penyalah guna dan pecandu narkotika. Sedangkan pada Pasal 54 UU Narkotika dinyatakan bahwa pecandu narkotika dan korban penyalahgunaan narkotika wajib menjalani rehabilitasi medis dan rehabilitasi sosial. Apabila menggunakan konstruksi Pasal 54 UU Narkotika ini maka penyalah guna narkotika tidak masuk dalam kualifikasi seseorang yang dapat diberikan tindakan rehabilitasi medis dan sosial sebagaimana diatur dalam Pasal 4 UU Narkotika.

Peristilahan yang digunakan dalam Pasal 4 dan Pasal 54 UU Narkotika tersebut juga berbeda 
dengan Pasal 103 UU Narkotika. Dimana dalam Pasal 103 memuat ketentuan mengenai pengobatan dan/atau perawatan dapat diputus atau ditetapkan oleh hakim bagi pecandu narkotika yang bersalah atau tidak bersalah melakukan tindak pidana narkotika dan istilah yang digunakan adalah pecandu narkotika. Terhadap satu konteks bahasan yang sama yaitu pemberian rehabilitasi medis dan sosial terdapat beragam peristilahan (penyalah guna, pecandu narkotika, dan korban penyalahgunaan narkotika).

Selain dalam konteks bahasan pemberian rehabilitasi, permasalahan pengertian ini juga menjadi simpang siur dalam ketentuan pemidanaan. Misalnya, Pasal 127 UU Narkotika yang menggunakan istilah "penyalah guna" dan "korban penyalahgunaan narkotika". Dalam ayat (2) pasal tersebut dinyatakan bahwa hakim dalam memutus wajib memperhatikan ketentuan Pasal 54, 55, dan 103 UU Narkotika, namun sayangnya istilah "penyalah guna" justru tidak ditemukan, hanya untuk "penyalah guna sebagai korban".

$$
\text { Dalam UU Narkotika, }
$$

setidaknya terdapat 4 (empat) pengertian bagi pengguna narkotika yaitu pecandu, penyalah guna, korban penyalahgunaan, dan pasien narkotika. Pecandu Narkotika diartikan sebagai orang yang menggunakan atau menyalahgunakan narkotika dan dalam keadaan ketergantungan pada narkotika, baik secara fisik maupun psikis. Sedangkan penyalah guna adalah orang yang menggunakan narkotika tanpa hak atau melawan hukum. Lalu, korban penyalahgunaan narkotika diartikan sebagai seseorang yang tidak sengaja menggunakan narkotika karena dibujuk, diperdaya, ditipu, dipaksa, dan/atau diancam untuk menggunakan narkotika. Terhadap pasien, tidak ditemukan pengertiannya. Namun, apabila merujuk kepada Pasal 53 UU Narkotika, dapat diartikan bahwa pasien adalah seseorang yang diberi hak untuk memiliki, menyimpan, dan/atau membawa narkotika dalam jumlah dan jenis terbatas sesuai dengan persetujuan dokter demi kepentingan pengobatan.

UU Narkotika mengatur definisi pecandu, penyalah guna, serta korban penyalahgunaan narkotika. Bagaimana UU Narkotika mendefinisikan dan menempatkan ketiga subjek hukum dalam konteks penegakan hukum narkotika dan rehabilitasi memiliki pengaruh yang sangat besar terhadap kemungkinan ditempatkannya seseorang di lembaga rehabilitasi.

a. Kriminalisasi Kepada Pecandu, Penyalah Guna dan Korban Penyalahgunaan Narkotika

Salah satu tujuan UU Narkotika adalah menjamin upaya rehabilitasi medis dan sosial bagi pecandu dan penyalah guna narkotika. Dalam UU Narkotika yang sebelumnya (Undang-Undang Nomor 22 Tahun 1997 tentang Narkotika), hal tersebut tidak dijadikan sebagai tujuan. Dengan demikian, adanya tujuan tersebut di dalam UU Narkotika yang baru, membawa angin segar bagi perjuangan pecandu atau penyalah guna narkotika untuk memperoleh pemulihan ketergantungan narkotika melalui rehabilitasi, dibandingkan dengan dipenjarakan. Namun ketentuan Pasal 127 ayat (1) memberikan ancaman pidana maksimal 4 tahun penjara kepada penyalah guna narkotika 
bagi diri sendiri atau dapat dikatakan mengkriminalisasi penyalah guna narkotika. Sehingga apabila seseorang terbukti bersalah melanggar Pasal 127 ayat (1) UU Narkotika, penyalah guna tersebut tidak secara otomatis mendapatkan putusan rehabilitasi. Pendalaman lebih lanjut mengenai Pasal 127 ayat (1) UU Narkotika dan ketentuan pidana lainnya dalam UU Narkotika itu sesungguhnya menunjukkan suatu ketidakjelasan. Berikut adalah beberapa pasal-pasal lainnya:

berbunyi:

Pasal 111 ayat (1) Narkotika

"Setiap orang yang tanpa hak atau melawan hukum menanam, memelihara, memiliki, menyimpan, menguasai, atau menyediakan Narkotika Golongan I dalam bentuk tanaman, dipidana dengan pidana penjara paling singkat 4 (empat) tahun dan paling lama 12 (dua belas) tahun dan pidana denda paling sedikit Rp800.000.000,00 (delapan ratus juta rupiah) dan paling banyak Rp8.000.000.000,00 (delapan miliar rupiah)."

Perbedaannya dengan Pasal 112 ayat (1) UU Narkotika adalah pada bentuk narkotikanya, yaitu berbentuk tanaman atau bukan tanaman. Pasal 112 ayat (1) UU Narkotika berbunyi:

"Setiap orang yang tanpa hak atau melawan hukum memiliki, menyimpan, menguasai, atau menyediakan Narkotika Golongan I bukan tanaman, dipidana dengan pidana penjara paling singkat 4 (empat) tahun dan paling lama12(duabelas)tahun dan pidana denda paling sedikit Rp800.000.000,00 (delapan ratus juta rupiah) dan paling banyak Rp8.000.000.000,00 (delapan miliar rupiah)."

Lalu, Pasal 114 ayat (1) UU Narkotika menyatakan bahwa:

"Setiap orang yang tanpa hak atau melawan hukum menawarkan untuk dijual, menjual, membeli, menerima, menjadi perantara dalam jual beli, menukar, atau menyerahkan Narkotika Golongan I, dipidana dengan pidana penjara seumur hidup atau pidana penjara paling singkat 5 (lima) tahun dan paling lama 20 (dua puluh) tahun dan pidana denda paling sedikit Rp1.000.000.000,00 (satu miliar rupiah) dan paling banyak Rp 10.000.000.000,00 (sepuluh miliar rupiah)."

Ketentuan dalam Pasal 111, Pasal 112, dan Pasal 114 terdapat permasalahan dalam perumusan normanya. Karena tidak disebutkan secara tegas bahwa pasal ini ditujukan untuk mereka yang dengan sengaja menyimpan, memiliki, atau bahkan menguasai narkotika bukan dengan tujuan untuk konsumsi sendiri melainkan untuk perdagangan gelap narkotika. Perlu disadari bahwa ketentuan pidana dalam UU Narkotika hanya mengatur predikat atau tindakan apa yang dapat dipidana. Tindakan yang dikenakan pidana diantaranya adalah memiliki, menguasai, membawa, membeli, menjual, mengimpor, dan mengekspor narkotika. Ketentuan pidana yang berpijak pada tindakan inilah yang sering kali menghalangi penegakan 
pengaturan wajib rehabilitasi bagi pecandu, penyalah guna, dan korban penyalahgunaan narkotika. Sebab, ketentuan pidana dalam UU Narkotika tersebut tidak melihat apakah orang yang membeli atau menguasai narkotika itu hanya bertujuan untuk digunakan sendiri bukan untuk untuk diperjualbelikan seperti bandar narkotika. Hal ini membawa konsekuensi kepada tertutupnya kemungkinan bagi pengguna narkotika untuk ditempatkan dalam lembaga rehabilitasi medis maupun sosial.

Seorang pecandu/penyalah guna narkotika yang mau mengonsumsi narkotika hampir pasti akan membeli atau terlibat dalam transaksi jual beli narkotika. Ketika ia sudah membeli narkotika atau sekalipun narkotikanya diperoleh dengan tidak membeli, pasti ia kemudian akan memiliki atau menguasai narkotika tersebut. Begitupun halnya dengan korban penyalahgunaan narkotika. Ketika narkotika masuk ke dalam tubuhnya saat ia diperdaya, ditipu atau dipaksa, narkotika tersebut pasti berada dalam penguasaan si korban penyalahgunaan narkotika. Hal ini kemudian menjadi persoalan mengenai inkonsistensi posisi UU Narkotika yang memuat ketentuan pidana kepada pecandu/penyalah guna/korban penyalahgunaan narkotika yang tidak kompatibel dengan Pasal 54 yang mewajibkan pecandu menjalani rehabilitasi dan tujuan dari UU Narkotika yang termuat dalam Pasal 4 yang menjamin upaya rehabilitasi.

Oleh karena pentingnya menemukan solusi penegakan hukum yang mencerminkan nilai keadilan serta menjamin hak dasar pecandu/penyalah guna/korban penyalahgunaan narkotika, maka perlu ditinjau dengan menggunakan tiga kerangka pemikiran, yaitu:

1. Teori Kepastian Hukum (certainty of law). Kepastian hukum dapat dilihat dari dua sudut, yaitu kepastian dalam hukum itu sendiri dan kepastian karena hukum. Kepastian dalam hukum dimaksudkan bahwa setiap norma hukum itu harus dapat dirumuskan dengan kalimat-kalimat di dalamnya dan tidak mengandung pebafsiran yang berbeda-beda. Sedangkan kepastian karena hukum dimaksudkan, bahwa karena hukum itu sendirilaha adanya kepastian. Kepastian hukum secara normatif adalah ketika suatu peraturan dibuat dan diundangkan secara pasti karena mengatur secara jelas dan logis. Jelas dalam artian tidak menimbulkan keragu-raguan

(multitafsir) dan logis dalam artian menjadi suatu sistem norma dengan norma lain sehingga tidak berbenturan atau menimbulkan konflik norma. Konflik norma yang ditimbulkan dari ketidakpastian aturan dapat berbentuk kontestasi norma, reduksi norma atau distorsi norma.

2. Konsep kewajiban negara dalam menjamin hak dasar warga negara yang didukung oleh teori asal 
mula negara, yakni teori perjanjian masyarakat (contract social theory). Generalisasi dari pendapat Thomas Hobbes, John Locke, dan J. J. Rousseau tentang teori perjanjian masyarakat menghasilkan kewajiban negara to protect, to respect, to promote, and to fullfill terhadap hak dasar manusia. Kewajiban to protect merupakan kewajiban untuk melindungi hak dasar warga negara yang memerlukan langkahlangkah segera untuk memastikan bahwa pelanggaran hak dasar manusia oleh negara dicegah. Kewajiban to respect terkait dengan kewajiban negara untuk menghormati hak dasar manusia dengan memberikan perlakuan yang setara dan bebas diskriminasi. Kewajiban to promote pada dasarnya adalah kewajiban negara untuk menaikkan harkat dan martabat hak dasar manusia melalui peraturan-peraturan yang dibentuk. Sedangkan to fullfill adalah kewajiban negara untuk memenuhi segala jenis hak dasar manusia baik yang tergolong ke dalam hak sipil dan politik maupun hak ekonomi, sosial, dan budaya.

3. Konsep

pertanggungjawaban pidana, yang dituangkan dalam ketentuan pasal sehingga menjadi tolok ukur penjatuhan pidana. ${ }^{4}$

Hukum pidana Indonesia termasuk di dalamnya pembentukan sistem pemidanaan harus dijiwai oleh nilai-nilai Pancasila sebagai dasar falsafah bangsa Indonesia, yaitu nilai-nilai yang didasarkan pada Ketuhanan, Kemanusiaan, Persatuan, Kerakyatan dan Keadilan. Di Indonesia yang merupakan negara Civil Law System, yang lebih menitikberatan pada kepastian hukum, maka perumusan norma harus benar-benar memenuhi asas "Lex Certa" yaitu tidak dapat ditafsirkan lain, rumusan suatu norma harus jelas dan tegas, tidak mengandung konotasi lain dan dapat ditafsirkan lain. Ketidakjelasan dalam perumusan norma seperti ini tentu akan sangat mempengaruhi penegakan hukumnya. Pendekatan penegakan hukum narkotika yang terkesan represif atau punitive, yang tercermin dari ancaman pidana yang terlampau keras, sanksi dan penghukuman yang tidak proporsional, dan juga penggunaan pasal yang tidak tepat membuat hukum narkotika yang ada justru terlihat salah sasaran. Sementara yang perlu dipahami adalah bahwa pendekatan hukum yang terlampau keras bukan hanya bisa menjadi upaya yang kontra-produktif, tetapi juga ada biaya sosial dan ekonomi (social and economic costs) yang tidak sedikit.

Mengenai

Problematika

Pelaksanaan

\footnotetext{
${ }^{4}$ Sahid Hadi, "Reformulasi Kebijakan Narkotika: Penegasan Unsur Mens Rea Sebagai Jaminan Hak Pecandu Narkotika", Jurnal Peradilan Indonesia Teropong Volume 5, 2017, hal. 74-75.
} 
Nomor 35 Tahun 2009 tentang Narkotika, ialah:

a. Apabila dicermari lebih dalam, pembentuk UU Narkotika menyadari bahwa harus ada perubahan pendekatan penanganan terhadap pengguna narkotika, yaitu dari pendekatan pemidanaan kepada pendekatan kesehatan masyarakat. Namun, UU Narkotika tidak mengatur secara tegas dan jelas mengenai pengertian dan status antara pecandu, penyalah guna, dan korban penyalahgunaan narkotika. Oleh karena ketidakjelasan pengertian dan status tersebut, maka pengaturan-pengaturan lainnya menjadi bias dan simpang siur pada tataran implementasi. Salah satu dampak praktik yang bias dan simpang siur adalah dalam hal pemberian rehabilitasi medis dan sosial bagi penyalah guna, pecandu narkotika dan korban penyalahgunaan narkotika.

b. Ketentuan Pasal 127 UU ayat (1) mengkriminalisasi penyalah guna narkotika dengan pidana penjara maksimal 4 tahun. Ketentuan pasal tersebut jelas bertentangan dengan tujuan dari dibentuknya UU Narkotika itu sendiri, khususnya yang termuat di dalam Pasal 4 huruf d yang bertujuan menjamin pengaturan upaya rehabilitasi medis dan sosial bagi penyalah guna dan pecandu narkotika. Begitu pula dengan ketentuan dalam Pasal 111, Pasal 112, dan Pasal 114 yang terdapat permasalahan dalam perumusan normanya. Karena tidak disebutkan secara tegas bahwa pasal ini ditujukan untuk mereka yang dengan sengaja menyimpan, memiliki, atau bahkan menguasai narkotika bukan dengan tujuan untuk konsumsi sendiri. Sehingga pasal-pasal tersebut juga dapat menjerat pecandu, penyalah guna, bahkan korban penyalahgunaan narkotika.

c. Dengan menjatuhkan pidana penjara kepada penyalah guna, pecandu dan korban penyalahgunaan narkotika dan menempatkannya di Lembaga Pemasyarakatan memberikan ruang untuk melakukan kejahatan narkotika yang lebih luas. Dari yang awalnya hanya pemakai pemula atau coba-coba, dapat menjadi seorang pengedar atau bandar narkotika. Ditambah lagi dengan masalah terbatasnya akses pemulihan sehingga menyebabkan adiksi yang tidak tertangani dengan baik, sehingga apabila telah keluar dari Lembaga Pemasyarakatan ia masih dalam kondisi ketergantungan narkotika, dan memungkinkan kemudian hari ia kembali menjadi pengguna narkotika dan kembali berhadapan dengan proses hukum.

d. Berdasarkan data dari Sistem Database Pemasyarakatan (SDP) per-Desember 2017, jumlah narapidana pengguna narkotika terhitung sebanyak 34.438 orang dari total narapidana khusus sebanyak 98.013 orang. Hal tersebut berimbas kepada permasalahan overcrowded pada setiap Lembaga Pemasyarakatan yang ada di Indonesia karena didominasi narapidana pengguna narkotika dan membengkaknya dana yang perlu dianggarkan pemerintah untuk biaya makan para warga binaan tersebut. 
DAFTAR PUSTAKA

1. Mengenai urgensi kebijakan dekriminalisasi terhadap penyalah guna narkotika menurut Pasal 127 Undang-Undang Nomor 35 Tahun 2009 tentang Narkotika didapat fakta menarik karena kriminalisasi penyalah guna narkotika tidak memenuhi syarat-syarat atau kriteria untuk mengkriminalisasi suatu perbuatan menurut Soerjono Soekanto, dan kriminalisasi terhadap penyalah guna narkotika sejatinya bertentangan dengan tujuan dari dibentuknya UU Narkotika itu sendiri (Pasal 4 huruf d). Sehingga penting untuk mempertimbangkan pergeseran pendekatan kriminalisasi ke dekriminalisasi kepada penyalah guna narkotika.

\section{A. Saran}

Adapun saran yang dapat penulis berikan adalah sebagai berikut:

1. Perlu adanya sinkronisasi istilah terkait dengan pengertian dan status antara pecandu, penyalah guna, dan korban penyalahgunaan narkotika. Sebab dengan sinkronisasi ini, kesimpang siuran istilah dan terminologi yang berakibat pada tercabutnya hak-hak pengguna narkotika dapat diminimalisir.

2. Pasal 127 direkomendasikan untuk dihapuskan atau didekriminalisasi, karena ketentuan pasal ini bertentangan dengan tujuan UU Narkotika dibentuk, dimana dapat dilihat dalam ketentuan Pasal 4 huruf $d$ yang mengamanatkan bahwa negara berkewajiban untuk menjamin pengaturan upaya rehabilitasi medis dan sosial bagi penyalah guna dan pecandu narkotika.

\section{A. Buku}

Ali, Mahrus. Dasar-Dasar Hukum Pidana. Sinar Grafika, Jakarta, 2012.

Ali, Zainudin. Metode Penelitian Hukum. Sinar Grafika, Jakarta, 2015.

Arief, Barda Nawawi. Bunga Rampai Kebijakan Hukum Pidana, Citra Aditya Bhakti, Bandung, 1996.

Arief, Barda Nawawi dan Muladi. TeoriTeori dan Kebijakan Pidana. Alumni, Bandung, 1992.

Bakhri, Syaiful. Kejahatan Narkotik dan Psikotropika Suatu Pendekatan Melalui Kebijakan Hukum Pidana. Gramata Publishing, Jakarta, 2012.

Eastwood, Niamh, dkk. A Quiet Revolution: Drug

Decriminalisation Across The Globe. Release, London, 2016.

Fajar, Mukti dan Yulianto Achmad. Dualisme Penelitian Hukum Normatif \& Empiris. Cetakan Pertama. Pustaka Pelajar, Yogyakarta, 2010.

Godwin, John. Sebuah Pendekatan Kesehatan Masyarakat Terhadap Penggunaan Narkoba di Asia: Prinsip-Prinsip dan Praktik-Praktik Dekriminalisasi. International Drug Policy Consortium (IPDC), London, 2016.

Hamzah, Andi. Asas-Asas Hukum Pidana Edisi Revisi 2008. Rineka Cipta, Jakarta, 2010.

Krisnawati, Dani, dkk. Bunga Rampai Hukum Pidana Khusus. Pena Pundi Aksara, Jakarta, 2006. 
Ma'roef, M. Ridwan. Narkotika Masalah dan Bahayanya. CV. Marga Djaya, Jakarta, 1986.

Makaro, Moh. Taufik, dkk. Tindak Pidana Narkotika. Cet. Kedua. Ghalia Indonesia, Jakarta, 2005.

Marzuki, Peter Mahmud. Penelitian

Hukum Edisi Revisi. Kencana, Jakarta, 2014.

Misero, Yohan. Overdosis Pemenjaraan: Tinjauan Singkat atas Kebijakan Pidana bagi Pemakai Narkotika. LBH Masyarakat, Jakarta, 2017.

Moeljatno. Azas-Azas Hukum Pidana. Bina

Aksara, Jakarta, 1985.

Muladi. Kapita Selekta Hukum Pidana. Universitas Diponegoro, Semarang, 1995.

Mulyadi, Lilik. Kapita Selekta Hukum Pidana Kriminologi dan Viktimologi. Djambatan, Denpasar, 2007.

Novian, Rully dkk. Strategi Menangani Overcrowding di Indonesia: Penyebab, Dampak dan Penyelesaiannya. Institute for Criminal Justice Reform (ICJR), Jakarta, 2018.

Prakoso, Djoko, dkk. Kejahatan-Kejahatan Yang Merugikan dan Membahayakan Negara. Bina Aksara, Jakarta, 1987.

Sahetapy, J. E. Hukum Pidana. Liberty, Yogyakarta, 1996.
Saleh, Roeslan. Beberapa Asas Hukum Pidana Dalam Perspektif. Aksara Baru, Jakarta, 1981.

Siswanto. Politik Hukum Dalam UndangUndang Narkotika (UU Nomor 35 Tahun 2009). Rineka Cipta, Jakarta, 2012.

Soekanto, Soerjono, dkk. Kriminologi: Suatu Pengantar. Cet. Kedua, Ghalia Indonesia, Jakarta, 1985.

Sudarto. Hukum dan Hukum Pidana. Cet.

Ketiga. Alumni, Bandung, 1983.

Kapita Selekta Hukum Pidana.

Alumni, Bandung, 1986.

\section{B. Jurnal}

Hadi, Sahid. "Reformulasi Kebijakan Narkotika: Penegasan Unsur Mens Rea Sebagai Jaminan Hak Pecandu Narkotika". Jurnal Peradilan Indonesia Teropong Volume 5. Jakarta, 2017.

Hafrida. "Analisis Putusan Hakim Pengadilan Negeri Jambi Terhadap Pengguna/Pemakai Narkotika Dalam Perspektif Penanggulangan Tindak Pidana Narkotika di Kota Jambi". Jurnal Penelitian Universitas Jambi Seri Humaniora Volume 16. Jambi, 2014.

"Kebijakan Hukum Pidana terhadap Pengguna Narkotika sebagai Korban Bukan Pelaku Tindak Pidana: Studi Lapangan Daerah Jambi". Jurnal Ilmu Hukum Volume 3. Jambi, 2016.

Luthan, Salman. "Asas Dan Kriteria Kriminalisasi". Jurnal Hukum Nomor 1 Volume 16. Jakarta, 2009.

Ramadhani, Valentina Dea. "Pengadopsian Kebijakan Dekriminalisasi Illict 
Drugs For Personal Use Di Portugal Oleh UNODC". Jurnal Of International Relations Nomor 2 Volume 1. Semarang, 2015.

Simanungkalit, Parasian. "Model Pemidanaan Yang Ideal Bagi Korban Pengguna Narkoba Di Indonesia". Yustisia Volume 1 Nomor 3. Jakarta, 2012.

\section{Skripsi}

Ikhsan, Muhammad. "Pemberdayaan Masyarakat Oleh Badan Narkotika Nasional Terhadap Anak Sekolah di Kota Jambi". Fakultas Hukum Universitas Jambi. Jambi, 2018.

\section{Peraturan Perundang-undangan}

Republik Indonesia. Undang-Undang Tentang Narkotika. UU Nomor 35 Tahun 2009.

Republik Indonesia. Surat Edaran Mahkamah Agung Tentang Penempatan Penyalahgunaan, Korban Penyalahgunaan Dan Pecandu Narkotika Ke Dalam Lembaga Rehabilitasi Medis dan Rehabilitasi Sosial. SEMA Nomor 04 Tahun 2010.

\section{E. Akses Internet}

http://dedihumas.bnn.go.id/read/section/art ikel/2013/11/19/813/dekriminalisas i-penyalah-gunanarkotikadalamkonstruksi-hukum-positif-diindonesia

http://regional.kompas.com/read/2016/01/1 1/14313191/Buwas.Pengguna.Nark oba.di.Indonesia.Meningkat.hingga. 5.9.Juta.Orang

http://smslap.ditjenpas.go.id/public/krl/curr ent/monthly/year/2016/month/9 http://www.emcdda.europa.eu./html.cfm/in dex214059EN.html.26

http://www.unodc.org/documents/wdr/WD $\underline{\text { R_2009/WDR_2009_eng_web.pdf }}$

http://www.jaringnews.com/politikperistiwa/umum/43615/kepala-bnntahanan-narkoba-membludaklantaran-hakim-tak-terapkan-uunarkotika 